\title{
A Critical Reading of Western Newspaper Narratives of Rape in India and their Implications for Feminist Activism.
}

\author{
Tamsin Bradley \\ Reader in International Development Studies \\ University of Portsmouth, UK \\ with \\ Suti Sahariah \\ PHD candidate University of Portsmouth, UK \\ \& Obaid Siddiqui \\ Professor of Mass Communications \\ Jamia Millia Islamia, Delhi
}

\begin{abstract}
This article is based on a review of around 100 western English print press articles recording rape in India. No cases were reported prior to the tragic and brutal rape of Nirbhaya in Delhi on the $16^{\text {th }}$ December 2012. The article presents a critical analysis of the dominant discourses running through the articles and highlights the extent to which the colonial lens is still present as the main perspective through which India is viewed. The article highlights how press narratives are problematic for two main reasons. Firstly, because of the narrow reporting of only rape which suggests it occurs only to middleclass or modern urban women, the daily experiences of low-caste and Dalit women for example is ignored. Secondly, we identify the construction of a problematic-male who is labelled deviant, sexually feral and the key perpetrator of all rape violence in India. This article in no way denies the reality of violence against women in India, quite the contrary, but argues that the distorting imperialist picture emerging through the press does not support the work of feminist activists in India whose nuanced and complex understanding of the realities of violence must lead the way to eradicating it.
\end{abstract}

\section{Main Author}

Tamsin Bradley

Reader in International Development Studies

School of Languages and Area Studies.

Faculty of Humanities and Social Sciences,

University of Portsmouth

PO1 2UP, UK 
Tamsin.bradley@port.ac.uk

+4402392846143

Biography: Tamsin Bradley is an applied social anthropologist working in international development. She currently works on gender-based violence, specifically on media reporting of rape in India and projects exploring the prevalence and impact of cultural practices on women's lives, specifically FGM (in Sudan) and Dowry (in India). She has conducted research exploring the interfaces between gender, religion and development in India, Pakistan and also in Rwanda and Sierra Leone. She has published a number of books; Women Violence and Tradition: Taking FGM and other practices to a Secular State. (2011, London: Zed Press). Also the monographs; Gender and Religion in Developing Societies: Faith-based Organisations and Feminism in India. (2010 London: IB Tauris) and Challenging the NGOs: Religion, Western Discourses and Indian Women. London: I.B. Tauris, (2006 paper-back published in 2011).

\section{Introduction}

In Gaytri Spivak's highly influential article 'Let the Subaltern Speak' she argues that 'the ideological construction of gender keeps the male dominant. If in the context of colonial production, the subaltern has no history and cannot speak, the subaltern as female is even more deeply in shadow' (p287). In this piece we argue that, thanks to the work of feminist post-colonial scholars (such as Spivak), and activists there is a greater consciousness around the ways in which women are systematically oppressed and silenced in India. Oppression operates both at the level of discourse but also in day-to-day life. Despite inroads into breaking the silence that is itself oppressive, our research reveals that subaltern positions still exist in and through the ways in which the western media reports rape in India. As we will demonstrate the subaltern woman is silenced because reporters rarely document her experiences focusing instead on a narrow number of cases. There is a stark disconnect between feminist academics, activists and then the international print press when it comes to depicting the realities of violence against women in India. There is no denying that violence against women and girls in India is an urgent issue (Bradley and Pallikadavath 2013, Chacko 2003, Srinivasan 2005). However rape in India prior to December 2012 was barely reported in the international press. Since that date we archived a surge in the number of pieces focusing on the protests and recording only a selection of cases. In all the 100 articles archived only 4 different cases were covered, that of Nirbhaya, a Swiss woman, a gang rape of a photo-journalist in Mumbai and then an American tourist. These four cases do not represent the full spectrum of rape victims in India.

The narrow selection of rape cases covered by newspapers enforces the marginality of other groups of women. It presents an inaccurate portrayal of who gets raped in India which in turn could result in international responses founded on stereotypes rather than lived experiences. Feminist postcolonial theorists have through their deconstruction of a subaltern Indian woman highlighted the epistemic violence caused by discourses that ignore and thereby silence groups of people. Local activists tirelessly respond to this violence by raising the audibility of different groups of women whose oppression is deep-rooted and normalised. 
The international press is working counter to these groups; reinforcing, and reconstructing through their rape narratives the subaltern female subject.

Before going further we must also acknowledge that similar biases in reporting have been recorded within the Indian press (see Bradley forthcoming, Ray 1998). This article is by no means suggesting that a subaltern does not also exist in Indian print press also. However the analysis of that bias in addition to the international distortion of rape in India is too great a task for one article. It should also be noted that the databases and search engines themselves have been found to maintain a western perspective and therefore bias (Gitelman 2014).

Whilst there may be nothing new in the way in which the western media maintains a subaltern Indian woman (through lack of reporting particularly of poor low caste women's experiences of rape), our analysis highlights the emergence of a particular male subject, presented and labelled as deviant. Poor, rural male migrants newly arrived in Indian's big cities have become the focus for western press narratives in their clumsy attempt to explain why rape is such a problem for women in India. We argue that these men are constructed as problematic-male subjects through media reporting, which sums up the way in which they are represented through western press. Whilst the men found guilty of the Delhi rape can be located in this poor, low caste socio-economic group, and their crime was hideous and evil, the projection of a problematic-male subject will serve to construct a stereotype through which all men falling into this demography will be judged. Doubtless within this group, as with all social groupings, and as both the Delhi and Mumbai cases attest, lie men who fail to curb their objectification of women and feel justified in utilising violence to control, possess and defile them. However, the realities of the rape statistics both in India and across globe highlight that such men exist across the socio-economic-political spectrum (UN Report 2013). The construction of a narrow problematic-male subject fails to acknowledge this global reality and will therefore take us further away from eradicating rape from the lives of women.

In short, this article will critically analyse how western print press has unhelpfully simplified the context of rape in India by reducing victims and perpetrators into narrow categories. There is of course nothing new in arguing that the international press focuses on the creation of voyeuristic stories which sell papers. However we argue that by placing the press analysis first followed by the voices of activists we highlight a distinct difference in perceptions and insights. We argue that if the press could be a little less geared towards the sensational and be responsive and supportive in projecting activist viewpoints more often, then the international print press could considerably help in pushing forward with the changes needed to end rape. We therefore argue that the disconnect existing between the media and activist perspectives needs to be bridged so all actors committed to end rape can work more fruitfully together. Press reporters could in fact use their platforms to support and strengthen the work of activists.

This article is based on an analysis of western English newspaper reporting on Rape in India. Whilst we cannot claim to have captured every story published a systematic and intensive search was undertaken for a period of around two months (November and December 2013). In addition to the newspaper search interviews held with around twenty Indian activists and academics who work to end violence against women (interviewed between July 2013 and January 2014). For the newspaper research a media data base was 
used and we searched across the international (outside of India) print press. Each article found was virtually catalogued its contents summarised into a table to support our analysis. Although 5 years of reporting were looked at going back from October 2013, cases were only really covered in any volume following the Delhi case in December 2012. Across the English speaking press we archived a total of 100 cases, these include two cases in which white western women were the victims, the remaining articles focused on the Delhi and Mumbai cases (cited above). Some reporting took a broader perspective highlighting the problem India faces not just with rape but also other forms of gender-based violence insinuating that India is increasingly unsafe for women. A significant number of the articles looked to offer an explanation of why rape is prevalent - it is in these articles that we identified a common narrative highlighting the poverty and low caste status of rape perpetrators who target middle-class and/or modern educated women in urban centres. As stated above this narrative is inaccurate in the sense that perpetrators cut across socioeconomic and geographic boundaries and so too do the victims of rape. The fact that such a constructed image of a rapist has emerged needs to be interrogated and critiqued, it is, we argue unhelpful in developing a nuanced accurate picture of gender-based violence and how it manifests not just in India but across the globe.

The article is structured as follows, in the first section the theoretical frame will be presented that forms the critical lens through which the newspaper reporting is analysed. In particular we present a summary of Spivak's work on gender and the political concept of the subaltern. We also highlight the usefulness of the 'death by culture' critique introduced by Narayan (1997). The arguments make by both Spivak and Narayan will be shown to resonate strongly in the articles we archived. Section two will explore the ways in which particular groups of Indian women have been rendered marginal through and by the international press reporting. The implications of this silencing for feminist activism both inside and outside India will be considered. The third section will pull out key press articles that feed into and construct a male-problematic. We will show that the masculinity of low-caste rural male migrants is projected as deviant and a threat to 'modern' women. Once again the implications of this subject framing for a nuanced and accurate understanding of genderbased violence will be discussed. Lastly in a fourth section we will offer a number of views from Indian feminists, both activists and academics. The interview passages presented will help to evidence a disconnection between activist views and those expressed in the print press. As already stated the article makes the argument that if it could be bridged the print press represents an important vehicle through which to support activist efforts. In the conclusion the article will return to the argument that this disconnection must be bridged for more fruitful efforts to end rape in India to emerge.

\section{Death by Culture}

For something is happening here, anger is overtaking fear. The dam has burst. The debate the politicians want is one of law and order, but the radical one is about how to change the culture itself. And because this is India we are taking about a myriad of cultures. Somehow, though, through the shock and the trauma, this country is examining itself and its much-vaunted modernity does not look so modern. (The Guardian Suzanne Moore 31 ${ }^{\text {st }}$ December 2012) 
Narayan in her much cited work in 1997 highlighted the problematic focus on culture in trying to explain violence against women in non-western countries. As she persuasively stated;

\begin{abstract}
"I intend to argue that when such 'cultural explanations' are given for fatal forms of violence against Third World women, the effect is to suggest that Third World suffer 'death by culture'. I shall try and show that fatal forms of violence against mainstream Western women seem interestingly resistant to such 'cultural explanations', leaving Western women seemingly more immune to 'death by culture'. I believe that such asymmetries in 'cultural explanation' result in pictures of Third World women as 'victims of their culture' in ways that are interestingly different from the way in which victimisation of mainstream Western women are understood." (1997: 84-5)
\end{abstract}

Our analysis of the western media reporting clearly reveals that Indian culture itself is the dimension found wanting presented as endorsing violence against women including rape. For example in the following passage;

A benign cultural earthquake is necessary if the country, one of the world's four big boom economies, can be allowed to hold its head up in the civilised world. (The Times 31 ${ }^{\text {st }}$ December 2012).

Rape has risen as a particular horror, not because it has newly emerged as a problem in women's lives in India, but because it is seen to pose a specific threat to India's claims to modernity. As Moore, in the passage cited above states, "this country is examining itself and its much-vaunted modernity does not look so modern." However, Indian feminists argue that violence against women is caused by a patriarchal gender ideology that systematically devalues women at every level rendering them vulnerable if they dare to transgress tight behaviour codes (Basu 2001, 2009, Palriwala and Uberoi. 2005, Palriwala 2009). The problem therefore is this gendered ideology which cannot be reduced simply to culture. Cultural shifts alone are unlikely to spark the transformation in gender relations needed if rape is to end. This reality can be seen in the violent reactions or backlash to changes that have already occurred in women's lives. For example; increased employment opportunities which challenge cultural norms around women's traditional domestic roles have been met with increases in work based harassment (Bradley 2013 and see also interviews in section 4).

So given the world-wide realities of violence against women why then in the case of rape in India is 'culture' so prominent in the media explanations? This questions is also explored by Durham (2015). Out of the 100 cases we archived 70 directly refer to Indian culture as a key factor in the construction of a problematic-male perpetrator. Spivak offers a way of understanding the politicised nature of the western media reporting which she locates in a 'desire to conserve the subject of the West, or the West as Subject.' (1988: 271) This can clearly be seen in the binaries underpinning the reporting of rape in India. Common themes call into question the legitimacy of India's claims to modernity, contrasted against western societies seen to reflect civilised and progressive values.

The tone and moral questioning implicit in colonial narratives describing India's uncivilised culture continues to resonate in the newspaper reporting we archived. The passage below is a good example of the common tone of sentiments present in colonial writings on India.

Let us hope that a new day had dawned on India, and that these wretched sacrifices may be spoken of by future generations as things that were, before British dominion enlightened India (Courtright 1994. 47) 
The imperialist project Spivak talks of in her analysis of sati accounts is clearly resonating in accounts of rape in India. She identifies a catachresis in the narratives she reviews that deliberately misreads alternative narratives or interpretations distorting historical accounts for the purpose of adding strength to the imperialist project (see also Mani 1998, Leslie 1991 and Hawley 1994). This imperialist narrative is formed around 'a deviation from an ideal that is irreducibly differential.' (1988: 286) In the article below sati is presented alongside rape giving the impression that it is commonly practiced. The conflation of sati and rape in current newspaper reporting is unhelpful for various reasons. Only a handful of cases of sati were reported in the 1990s, it certainly was not widespread, as the scholars cited above argue it never in fact was. Rape is not unique to India yet the positioning of rape alongside sati suggests there is something country specific about it.

\begin{abstract}
Extreme violence against women may be nothing new in India, where sati, or widow burning, was practised as recently as the late 1990s. But the number of reported cases of rape and, in particular, gang rape, appears to have increased sharply in recent years. In 2011, there were more than 24,000 reported rapes in India, a 9.2 per cent rise over the previous year. The real figure is almost certainly far higher, as so many cases go unreported. (The Times March $20^{\text {th }}$ 2013)
\end{abstract}

So that leads us to Spivak's key question and the subject of the next section; can the subaltern speak? In her critique of the colonial narrative in which she identifies the silent subaltern woman, she frames the politics of imperialism as 'white men are saving brown women from brown men', echoes of this can be seen in the reporting on rape in India both in the ways in which groups of women are silenced and rendered subaltern through and in the pages but also in the construction of a male-problematic, from whom Indian women need saving. Two questions spring to mind; how accurate is this portrayal of the rape problem? And if it is correct who will act as the saviour? Given the volume of newspaper articles that highlight India's inadequate claims to modernity, it would seem that greater influence of western values and morality - will reverse the growing rape trend in India. Modern values are largely associated with the neo-liberal capitalist vision. As already stated at the start of this article, this model of growth is now thought to be responsible for a backlash and increases in violence against women (Amrute 2015, Edelman and Haugerud 2005, De Sousa, Santos 1999, Tinker 1999, Escobar 1995, Esteva 1993, Pottier, Bicker and Stilloe 2003). This view is also shared by some of the activists interviewed and presented in section four.

Let us now turn to the ways in which the subaltern woman remains through newspaper rape reporting.

\title{
2. The Missing Women
}

From our research we found that eighty-five articles written on rape in India focused solely on documenting the four cases the rape of a Swiss woman on holiday with her husband, the Delhi rape of Nirbhaya, the gang rape of an American tourist and the Mumbai case in which a young female photographer was attached. Arguably in all four cases the victims were urban, upwardly mobile women. There are obvious and glaring omissions; specifically poor, rural, low caste women for whom rape and other forms of gender-based violence represent a structural daily reality. According to the National Crime Records Bureau an average of 
ninety-two women are raped in India per day (The Guardian 2014). Research that digs down into how this figure divides according to class-caste is not yet in existence. However if we look at research that focuses on intimate partner violence (arguably the most common form of violence against women and girls) we can get something of a picture in terms of who the most vulnerable groups are. Paul (2014) used national survey data to look at this question of vulnerability. Women in the age group of 25-39 are most likely to suffer violence at home. Of the religious communities, Buddhist women (usually dalits) are most likely to suffer IPV. Jain women (who tend to be richer) suffer the least violence (Paul 2014). Of all 'social groups', scheduled caste women suffer most IPV. It is therefore not unreasonable to think that this pattern would repeat itself in instances of rape.

The passage given below is good example of how the press coverage hides and distorts the complex and diverse realities of violence against women in India. The article focuses in on the case of the Swiss woman brutally gang-raped, it then moves to the Delhi rape, and then to a case of an American woman, in between the cases country wide statistics on rape are given but no mention is paid to who these 24,200 rape victims actually are.

An Indian court has sentenced six men convicted of the gang rape of a Swiss woman to life imprisonment, a lawyer in the case said.

The 39-year-old Swiss woman was raped while camping with her husband in a forest in the central Indian state of Madhya Pradesh in mid-March. Three months earlier, a student was gang-raped and beaten in a moving bus and thrown bleeding on to the street in a case that triggered mass protests.

"It was a good judgment. It came early," said Rajendra Tiwari, a lawyer for the government.

The National Crime Records Bureau says more than 24,200 rapes were reported across India in 2011 - about one every 20 minutes. Police estimate only four out of 10 rapes are reported, largely due to victims' fear of being shamed by their families and communities.

The gang rape of a 23-year-old woman on a bus on Dec. 16 in New Delhi sparked a global outcry over the issue and brought thousands of people onto the streets to demand better policing to prevent sex crimes. The trainee physiotherapist later died from her injuries.

An American tourist was gang-raped by a group of men in a hill resort in northern India in June. In March, a British woman jumped out of her hotel balcony in Uttar Pradesh state to escape a feared sexual assault. (The Independent $20^{\text {th }}$ July 2013)

A significant number of the articles (35) subsequent to the $16^{\text {th }}$ December 2012 Delhi case highlight instances of rape against western women. Once again the focus on these cases, whilst utterly horrific, mask the realities of violence for so many other groups of women in India and in doing so does not help public understanding of the complexities of why rape persists.

A British tourist in India leapt $20 \mathrm{ft}$ from her hotel window fearing that she was about to be sexually attacked after a man allegedly tried to burst into her room. 
The incident has put a further dent in India's reputation as a relatively safe place for female travellers, coming days after the gang rape of a Swiss tourist.

Last Friday night a Swiss tourist was raped during a cycling holiday with her husband in Madhya Pradesh, about 125 miles from Agra. Six men charged with gang rape appeared in court on Monday.

The last sentence of this article is interesting as it highlights the revised UK Foreign Commonwealth Office travel advice given to British women thinking of traveling to India.

The Foreign Office updated its advice for female travellers this week, warning them to "use caution when travelling in India". (The Times March 20 ${ }^{\text {th }}$ 2013).

In reality India has not suddenly become a more unsafe place for women, and nor, when the global statistics are looked at, is it significantly more violent towards women then other places for which a similar warning is not given. The FCO is clearly responding to the hysteria generated by the cases reported in the press and although understandable, feeds into and supports this construction of Indian culture as uncivilised and dangerous.

Once again the problem is that such depictions of violence against women in India do not support a nuanced and complex understanding of how it manifests itself in women's lives. In short it does not support the work of activists who are trying to end it.

\section{The Problematic Male Subject}

We now turn in this section to how, through these newspaper articles, a problematic-male subject has emerged. This category of male perpetrator can be typified as newly migrated from a village to a city. They are poor and largely uneducated seeking to carve a living from low skilled, manual work. The following article in particular sums up the category of problematic male emerging across a significant number of articles (fifty-five out of one hundred archived).

Indian cities are awash with feral men, untethered from their distant villages, divorced from family and social structure, fighting poverty, exhausted, denied access to regular female companionship, adrift on powerful tides of alcohol and violent pornography, newly exposed to the smart young women of the cities, with their glistening jobs and clothes and casual independence - and not able to respond to any of it in a safe, civilized manner. This is the world of women under siege, the medieval world of the walking undead, the rise of the zombies, targeting females rich and poor. For women, at least, winter is coming. (International New York 21 ${ }^{\text {st }}$ October 2013).

The creation of this category of problematic male allows, to some extent, the image of modern aspirational India to remain. It places the blame for violence against women squarely on those that fit this category. According to the reports problematic men share character traits. They are volatile and untamed or rather and as described in the article cited above feral and untethered. The descriptions go beyond personality and dig into the immorality of problematic men linking their behaviour to the environment they inhabit:

Two of the killer-rapists came from a squalid slum colony of New Delhi called Ravi Das colony, one of dozens in the national capital, and thousands across the nation. While there are productive and even "dynamic" slums, such as Dharavi in 
Mumbai (Asia's largest), which has thriving industries in its midst, many if not most slums are hotbeds of despair, alcoholism, drug abuse and lawlessness where police do not bother or dare to even enter.

A lot has been said about the need to change Indian males' centuries' old misogynistic attitudes and backward mindsets towards women, (The Business Times - Singapore $18^{\text {th }}$ September 2013).

Key words/descriptions recurring though a number of the articles include; 'hotbeds of despair, alcoholism, drug abuse and lawlessness', a vivid picture is painted of the environment in which the perpetrators emerge and the reader is left with no doubt over the likely character and moral dysfunction instilled through such places. Other passages go further in offering explanation as to how this moral underclass arrived in India's shinny metropolis. Highlighting how out of place and ill at ease they must be surrounded by 'modernity' and 'civilisation'.

Delhi itself has a particular problem because tens of thousands of newly urbanised people, from villages still almost medieval, live alongside modern workers including liberated women. Many young men consider "Eve-teasing" (the disgustingly coy subcontinent euphemism for sexual harassment and assault) as their male birth right. The rapists in this case were, we are told, from this demographic; their victim a medical student whose parents sold their land to pay for her education. (The Guardian April 2013)

The backwardness of this 'male-problematic' is once again highlighted in this passage constructed against the advanced mobility of India's city populations. The word 'medieval' clearly resonates and reflects the kind of language used by colonisers intent on projecting a narrative of Indian culture as backward. The dark picture painted by the use of such words continues through many of the articles we looked at. Presented below are two passages taken from the fifty-five articles which are representative of the comments and language used in all of them.

In a country where reported sexual violence is increasing - despite heightened attention to the problem - many say the women-only spaces are a welcome refuge from lewd looks, groping and unwanted male attention. (Washington Post $28^{\text {th }}$ September 2013)

A variety of explanations have been offered up, from a widening gender imbalance, to rapid urbanisation, which has left huge numbers of rootless young men, often with little education and few opportunities. (The Times March $20^{\text {th }}$ 2013)

These passages (and many others) describe a violent tension playing out on India's city streets as women strive for a modern independent life. It points to resentment experienced by those who do not feel included in India's economic success. Whilst this clash between modernity and poverty is seen as part of the trigger resulting in the backlash and rising levels of violence (picked up also by the activists interviewed in section 4), it is not the whole story. Furthermore the focus in on one category of male perpetrator hides the realities that violence against women is normalised across social and economic groups. As the activists we interviewed clearly articulate, the problem is the acceptance that violence is a legitimate way of controlling women. Putting the blame on one 
category of man does not help unravel and deconstruct the root of gender oppression.

Another characteristic give to the male-problematic is a rampant sexuality that is rendered wild by the sight of young Indian women displaying their liberation (so it is suggested), for example in wearing western style dress. So the story unfolds in these articles of a male-problematic emerging as the enemy to modern Indian women, lusting over their bodies, resentful at the success they seem to have achieved. This is clear by the passage below.

Such men see successful and ambitious young women on their way to work in short skirts, laughing and holding hands with boyfriends. Cue scorn, anger, envy and lust. I put lust at the end of that list, because rape has always had an element of contempt, a desire to put uppity women in their place. Ask any prison psychiatrist: serial rapists often hated their mothers or were rejected by girls. (The Times $31^{\text {st }}$ December 2012).

The article written by Jason Burke in The Guardian offered a more nuanced focus presenting indepth life histories of the perpetrators. Despite its attempt to give a more complex understanding of the behaviour behind the Delhi rape it still supports the existent of a homogenous problematicmale subject.

Ram and Mukesh Singh, 34 and 26 years old, Ravi Das Colony had been home for most of their lives. Ram earned a living as the driver of a bus that, albeit without the necessary permits, carried schoolchildren. Ram's brother, fired from a dozen jobs, intermittently drove a taxi.

The two had grown up on a small homestead in Karauli, a remote eastern part of the state of Rajasthan, five hours by train from the capital. They attended a local school with few facilities and an often absent teacher, playing in the fields and dried riverbeds. They came to Delhi in 1997. India was then beginning to boom after the reforms of the early 1990s injected a new capitalist energy into the sclerotic, quasisocialist-quasi-feudal economy, and their landless labourer parents decided to try their luck in the capital.

Though they left local girls alone, the Singh brothers were known among their neighbours for drunkenness, petty crime and occasional, unpredictable violence.

Both the 17-year-old, known as Raju, and Thakur had their own troubled histories. Their paths had taken them through a side of India that has less to do with the emerging economic powerhouse of international repute and more to do with a tenacious, older India riven by conflict, poverty, chaos and random violence.

The eldest of five children, Raju was born to a destitute day labourer with mental health issues and his wife in a village 150 miles east of Delhi, in the vast northern state of Uttar Pradesh which has 180 million inhabitants and socio-economic indicators often worse than those in sub-Saharan Africa.

The piece ends with Burke commenting on the wider social-cultural environment highlighting the normalisation of violence against women in the daily lives of these perpetrators. He highlights the 
prevalence and normalisation of violence in rural settings thus indicating that as rural- urban migration has increased so the culture of rape has permeated cities.

As in rural Rajasthan, where the Singh brothers came from, women in the countryside of Uttar Pradesh suffer systematic sexual harassment and often violence. Rape is common and gang rape frequent. Victims are habitually blamed for supposedly enticing their attackers. Many are forced to marry their assailants; others kill themselves rather than live with the social stigma of being "dishonoured". Police rarely register a complaint, let alone investigate. (The Guardian $10^{\text {th }}$ September 2013)

This article is novel in its approach and attempt to get close to the perpetrators and understand the social-cultural-economic contexts from which they come. However the piece does not give space for any man fitting the problematic-male profile to speak for himself and perhaps challenge the homogenous assumption that all poor village men behave as these did. Furthermore, rape and gender-based violence generally is not a cultural product but shaped by a particular gender ideology based on power relations that privileges some at the expense of others. Social inequalities are at the heart of the violence women and girls suffer. Wealthy high caste men are rapists too; rape victims are also poor and low caste.

The male-problematic pinpointed in our analysis has become a useful subject onto which to pin the blame for rape and indeed other forms of gender-based violence. The reality that rape perpetrators cut across socio-economic and caste lines is missed and in itself produces an epistemic violence which further marginalises and problematises a particular group of men who already struggle to carve out a dignified existence. As Spivak states in relation to the colonial construction of a subaltern woman:

'Yet the assumption and construction of a consciousness or subject sustains such work and will, in the long run, cohere with the work of imperialist subject-constitution, mingling epistemic violence with the advancement of learning and civilization. And the subaltern woman will be as mute as ever.' (295)

And so this story of imperialist subject-constitution remerges yet again in the creation of a homogenous rape perpetrator and through the absence of a diversity of rape victims. This male-problematic is now feared not just in India but globally. For example in the passage below:

This week in Singapore, a young woman told me how she had put off a longdreamed of trip to India.

"I'd been hoping to go for a spiritual retreat but then there was all that stuff with the rape case," she said. "So instead, I planned a trip with my family to Thailand." On Tuesday, she hopped on a plane to Bangkok. (Singapore Times February 2013)

This passage highlights the influence and impact press reporting clearly has, as if we did not know, in shaping public perspectives, behaviour and responses, inaccurate reporting therefore has dangerous consequences. The narratives we have presented clearly do more to support the continuation of an imperialist project then they contribute to the feminist campaign to end violence against women. In order to get a more complex picture of the why 
and how questions surrounding violence against women we now move our focus to the views of some feminist activists in India.

\section{The Views of Activists}

A number (around 20) activists were interviewed all engaged on the ground with fighting violence against women. They were asked about how they understood the problem, its prevalence now and whether it has changed and lastly what they saw as the root causes. The analysis of the interviews explores the extent to which the views of activists do not support the newspaper narratives identified in this article. What emerges is a clear disconnect between the experiences and accounts of activists working directly to end rape and other forms of violence and the viewpoints and narratives that dominate the international print press.

\section{An Academic-Activist}

A leading Indian feminist activist and academic, highlighted that underlying misogynistic views on women have shifted very little: ${ }^{1}$ I think that often we can see that there is a backlash because more women are speaking out, even Dalit women, yet there is increasing violence against Dalit women, and widows especially. Widows are supposed to remember they should be quiet and not speak out. So there is a dual thing: women are speaking out on the one hand but facing the backlash, in some cases entrenched views and insecurities that come out.

She went on to explain that the failure of liberalisation to dramatically improve people's lives has meant that, if anything, women have become more vulnerable to violence, as those men who were promised a better life (which has not emerged) vent their anger:

With liberalisation many promises were made of better lives but many have not seen things get better, so who are you going to blame? So I think it is not just violence against women which has increased in the Indian context; the cases of violence against Dalits, against widows, particular sections of women, have increased. For someone like me, I really have to be jolted to see how things have changed. As a young woman travelling by bus I would experience those things every day walking along the street - now, it is very rare that I am on the street so I don't see it, I am in a position of power so I don't experience that now, but I experience humiliation in other ways.

She was then asked how things could change:

There needs to be a realisation that we are not going to address women's gender oppressions unless we address all inequalities, unless we address class inequalities, all these various different things. And this is becoming more and more stark and of course making it more and more difficult, because it is almost impossible to get an overarching constituency which will campaign on all these issues. So what can we do? We have to keep addressing each of these things by themselves as well as the gender ideology embedded in them.

\footnotetext{
${ }^{1}$ Interview conducted January 2014
} 
In relation to the press reporting of violence against women, the distortion comes through in the over-emphasis of some forms of violence and a lack of holistic coverage across the abuses women suffer:

Almost any issue in relation to women is framed in terms of gender violence, yet there are many more forms of violence that do not get recognised, and issues such as dowry, sex selective technologies, discussion around the anti-rape law. Since last decade rape became the major issue focused on in relation to violence against women and it became a major issue of reporting in the papers. I think some of us were getting sick and tired with the fact that, ok, every day there are going to be three cases reported on the front pages and the on the inside pages, and you know it is good that the media is focusing on it, but is this the way to focus on it?

\section{Younger Activists}

A second interview was conducted with a younger activist who has a leading role working for the All-India Democratic Women's Association. She spoke about how difficult her organisation finds engaging with the media. ${ }^{2}$

It is hard to reach the media, and we feel the media is more interested in newer issues, which is excellent: the issues of smaller sections also need to be reflected, but what we are saying is that the large majority are still stuck with issues of violence and sexual assault that happens in more marginalised sections - poor women and Dalit women - and as far as the media is concerned they are looking for a story and ready-made press releases, which we as a women's organisations find ourselves pretty incapable of providing them with. We would love to influence them in covering the issues we are interested in, We would give them ready-made material around it.

As with the previous interview, feelings expressed here suggest that the media is not reporting a holistic picture of violence against women, but rather focusing in on a narrow range of cases. This was borne out in the analysis of rape-reporting also given above, and indicates that these scholars and activists at least feel the press is not supporting their work and perspective on violence against women.

Again, as with the academic above, the activist also raised the issue of the narrow focus on certain types of violence. She raises this issue not just in the context of media coverage but also at the levels of national and global policy making. It is her view that actors across the media, government and global institutions ignore even some of the most common and persistent forms of violence against women such as dowry harassment:

Dowry has been out on the back burner - UN Women, for example, constantly shifts the issue; dowry has become a boring issue so to say, that organisations and NGOs avoid getting into direct conflict with communities but when working on issues such as honour crime you have to get into confrontation with certain

\footnotetext{
${ }^{2}$ Interview conducted January 2014.
} 
people. And so then for an organisation like ours we find ourselves pretty lonely even though there are so many organisations working on women's issues we find ourselves completely isolated.

The activist also raised the issue that certain groups of women such as Dalits are more vulnerable to violence. She responded: So, with sexual assault you cannot ignore the fact is faced by Dalit women more aggressively than any other section, and they may not want to talk about caste so that's the problem.

As raised by this AIWDA activist, the context and nature of violence differs in rural areas when compared to urban. A director of a women's organisation located in Himachal Pradesh stated that in rural areas violence is much less talked about publicly, but that it is a big problem; in particular, domestic violence, but also high levels of female infanticide. These nuances, differences and realities rarely find their way into the international print press. An activist working for the Lawyers Collective in Delhi highlighted the extent to which gender discrimination is deep rooted. The problem does not rest with one section of society but is epidemic.

The whole system is fundamentally chauvinist. It is difficult to implement these laws within a chauvinistic system and there remains an under-reporting of rape, mainly due to an ineffective police service. More training and capacity-building within the police is needed. Also, need more female police officers to whom women can report.

The need to dig further in understanding the root of violence against women comes through in an interview with a male anti-trafficking activist. He stated: ${ }^{3}$

Only when we change the mind-set of the people both in rural and urban areas... in a positive way, where we respect women, where we respect our children and family... India as you know is a family-oriented society. That has changed... we are going more towards nuclear families even in rural areas, so that problem is rising. And you know, years of negligence has brought up at this point because we never spoke against violence on women, we never understood the types of problems women face... Neither our central government was speaking. We have Women and Child Ministry but they never took up these issues on a priority basis. Violence was happening in houses - it was hidden.

Activists such as all those documented here are pushing for a fundamental attitude change. The same male activists stated:

Gender inequality it is very deep-rooted. It is so deep-rooted that, despite being educated the choice or decision is not hers, it's her husband's and his family that matters. If a girl is making her own choice, she is branded as someone wrong. They don't respect the family and even the husband starts abusing. Because the husbands think that the wife should respect the family

\footnotetext{
${ }^{3}$ Interview conducted January 2014.
} 
of the husband. It's a tradition that you have to do. But as girls more educated they have their own choice. They want to do their life happily and a few very girls walk away... it's very tough to walk away.

The engagement of men in fighting gender inequality is not often recorded, but clearly vital if this kind of attitude shift is going to occur:

What comes through in these interviews are a number of linked themes and issues which help to give a more comprehensive picture of why women across the spectrum are vulnerable to violence. The interviews also highlight that the perpetrators of violence do not come from one socio-economic group. The problem is not so much cultural but is about gender or specifically an ideology that systematically devalues women at every level. The journalists who wrote about rape in India failed to convey this and instead rested with an overly simplistic and essentialist reading of the rape-problematic.

\section{Conclusions}

This article has presented an analysis of western English speaking print press reporting of rape in India. The findings revealed that rape in India was barely reported prior to the Delhi case of December 2012. In reviewing the cases a worrying, but perhaps not unsurprising, narrative can be seen resonant of the colonial discourse in which India is projected as uncivilised and not yet enlightened. This narrow reporting of rape cases, although depicting an undeniably brutality, has opened up an uncomfortable reality highlighting that the colonial lens is still the dominant perspective through which India is viewed in western public discourses. These negative colonial narratives are seen across the broadsheet and tabloid press some with shocking blatancy in their directness accusing India of barbarism and backwardness. The word 'uncivilised' is used in numerous articles to characterise Indian society. The realities of violence against women in India has not been denied at any point in this article, but rather the argument has been made that the presentation of distorted and negative images of how and why gender-based violence manifests itself in India does not support the work of activists who have campaigned on this issue for decades. The views of activists working to end violence against women in India clearly highlights a disconnection between their insights and that of the international print press. The complex nexus of violence in India, as across the globe, is lost in the over simplification and demonisation of a relatively small section of the population. As highlighted from the start only a small group of Indian women are acknowledged as victims ignoring the plight of many who face daily atrocities of sexual, physical, psychology and economic violence.

Ironically in maintaining this colonial narrative in the reporting of rape the press commits an act of violence and recreating a subaltern woman subject. Gender-based violence is a problem in India, there is no doubt about that, but the false representation of a singular homogenous category of perpetrator does not bring us closer to unravelling the gendered web that supports many forms of abuse and injustices against women. This article urges critical reflection on the part of the media who need to go further in deconstructing the imperialist lens through which it views and represents India. From the start we argued that the media should work more closely with activists committed to ending violence. The platform of the print press is a powerful one that could and should be captured for more 
positive transformative ends. Giving voice to the experiences of activists is one way of trying to bridge this gap and urge a more critical and insightful press discourse on rape in India.

\section{References}

Amrute, S. 2015. Moving Rape: Trafficking in the Politics of Postliberalization, Public Culture, 27(2): 331-359.

Basu, S. 2001. She Comes to Take Her Rights: Indian Women, Property and Propriety. New Delhi: Kali for Women.

Basu, S. 2009. "Legacies of the Dowry Prohibition Act in India: Marriage Practices and Feminist Discourse." In Dowry: Bridging the Gap Between Theory and Practice, edited by T. Bradley and E. Tomalin, 177-196. Delhi: Women Unlimited and Zed Press.

Bradley, T and Pallikadavath, S. 2013. Dowry and women's lives in Kerala: what has changed in a decade?, Contemporary South Asia, Vol. 21, No. 4, 444-461.

Bradley, T .forthcoming 2016. Women and Violence in India: Gender, Oppression and the Politics of Neoliberalism. London: IB Tauris.

Chacko, E. 2003. "Marriage, Development, and the Status of Women in Kerala, India." Gender and Development 11 (2): 753-773.

Courtright, P. 1994. 'The Iconographies of Sati', in Hawley, J. eds. Sati: the Blessing and the Curse. Oxford: Oxford University Press. p27-48.

Daly, M. 1979. Gyn/Ecology: the Metaethics of Radical Feminism. London: The Women's Press.

De Sousa, Santos, B. 1999: On oppositional postmodernism. In Munck, R. and O'Hearn, D.,editors., Critical development theory contributions to a new paradigm. Zed Books, 29-34.

Dirks, N. 2001. Castes of Mind Colonialism and the making of modern India. New Jersey: Princeton University.

Dirks, N. 1989. 'The Invention of Caste: Civil Society in Colonial India', Social Analysis: the International Journal of Social and Cultural Practice 25:42-52.

Durham, M, G. 2015. Scene of the Crime: News Discourse of rape in India and the Geopolitics of Sexual Assault, Feminist Media Studies 15(2): 175-191.

Edelman, M. and Haugerud, A., editors. 2005: The anthropology of development and globalization: from classical political economy to contemporary neoliberalism. Blackwell.

Escobar, A. 1995: Encountering development: the making and unmaking of the third world. Prinkel.

Esteva, G. 1993: Development. In Sachs, W., editor, The development dictionary: a guide to knowledge as power. Zed Books, 6-25. 
Gitelman, L. 2014. Searching and Thinking about Searching, Representations 127(1): 73-82.

Hawley, J. 1994. eds. Sati: the Blessing and the Curse. Oxford: Oxford University Press. Leslie, J. ed. 1991. Roles and Rituals for Hindu Women. London: Pinters.

Mani, L. 1998. Contentious Traditions: The Debate on Sati in Colonial India. Delhi: Oxford University Press.

Mayo, K. 1927. Mother India. Michigan: Michigan University Press.

Mohanty, C, T. 2003. Feminism Without Borders: Decolonizing Theory, Practicing Solidarity. Durham and London: Duke University Press.

Narayan, U. 1997. Dislocating Cultures: Identities, Tradition and Third World Feminism. New York: Routledge.

Palriwala, R. 2009. "The SpidersWeb: Seeing Dowry, Fighting Dowry." In Dowry: Bridging the Gap

Between Theory and Practice, edited by T. Bradley and E. Tomalin, 144-176. New Delhi: Women Unlimited and Zed Press.

Palriwala, Rajini, and Patricia Uberoi. 2005. "Marriage and Migration in Asia." Special Issue Indian Journal of Gender Studies.

Pottier, J., Bicker, A. and Stilloe, P., editors. 2003: Negotiating local knowledge: power and identity in development. Pluto Press.

Ray, R. 1998. Women's Movements and Political Fields: A Comparison between two Indian Cities, Social Problems 45(1): 21-36.

Spivak, G, C. 1988. 'Can The Subaltern Speak', in Nelson, C and Grossberg L, eds. Marxism and The Interpretation of Culture. Urbana and Chicago: University of Illinois Press.

Srinivasan, S. 2005. "Daughters or Dowries? The Changing Nature of Dowry Practices in South

India." World Development 33 (4): 593-615.

Tinker, I. (1999) 'The myth of development: a critique of a Eurocentric discourse', in R. Munck and D. O'Hearn (Eds), Critical Development Theory Contributions to a New Paradigm. London Zed Books.

United Nations. 2013, The Millennium development Goals Report. UN. 